https://doi.org/10.22364/hssl.28.1.05

\title{
LATVIAN-FINNISH ECONOMIC RELATIONS $1918-1940^{1}$
}

\section{Viesturs Pauls Karnups}

Dr. oec.

\begin{abstract}
This article provides an overview of Latvian-Finnish economic relations in the interwar period. In the interwar period, economic relations between Latvia and Finland were mainly confined to foreign trade, although there were some investments in Latvia from Finland as well. Latvia declared its independence in 1918, however normal trade with Finland did not commence until 1920 after the end of the Latvian War of Independence. It ended with the outbreak of the Winter War in 1939. Latvia's foreign trade in relation to Finland was more or less regulated by the 1924 Commercial and Navigation treaty, as well as the 1936 Commercial Agreement. Latvia's main imports from Finland in the interwar period were textiles and textile products, metals and metal products, cellulose, paper and paper products, agricultural machinery, and knives and knife products, whilst Latvia's main exports to Finland were rubber products, gypsum, bone meal, paint and paint products, seeds, radios and linoleum. In general, trade and thus economic relations were of marginal significance to both countries in the interwar period due mainly to the similarities of their economic structures. On the other hand, Latvia had fairly intensive relations with Finland in the political, social and cultural spheres. This was mainly due to the fact of geographic propinquity, and Finland's special relationship to Estonia, which was Latvia's neighbour and closest ally.
\end{abstract}

Keywords: Latvia, Finland, economic relations, interwar period

\section{Introduction}

Although Latvians had had sporadic contact with the Finns in previous centuries, especially after Finland was annexed to the Tsarist Empire, it was in the aftermath of the 1905 revolution and during WWI that a large number of Latvian intelligentsia (writers, public figures, etc.) found refuge in Finland. ${ }^{2}$ After WWI and into the 1920s, Finland was regarded as a Baltic State along with Estonia, Latvia, Lithuania and to a lesser extent Poland.

1 A version of this article was presented at the International conference: $13^{\text {th }}$ Swedish Economic History Meeting in collaboration with the $1^{\text {st }}$ Annual Conference of the Scandinavian Society for Economic and Social History, Uppsala, Sweden, 10-12 October 2019.

2 In 1916, there were some 200 Latvians living in Helsinki (Krasnais (1980), p. 79). 
Later Finland was included with the Scandinavian countries. In the early 1920s, the Latvian Foreign Minister, Z. Meierovics, tried to involve Finland in the creation of political and economic blocs with the other Baltic States, but to no avail. ${ }^{3}$ Finland distrusted Poland and did not want to be involved in the Lithuanian-Polish conflict over Vilnius. While Estonia and Latvia in particular were quite unfriendly to Germany, Finland, on the other hand, not only felt gratitude to the Germans for their assistance in their War of Independence, but cultivated German influences in their cultural life. By 1926 Finland had practically terminated its close co-operation with the other Baltic States and turned to the Scandinavian countries for acceptance into the Nordic Bloc. ${ }^{4}$ From then on co-operation between Finland and Latvia was mainly in the cultural sphere, vaguely in the military sphere (on a purely informative basis), and economic relations.

Finland recognised Latvia de facto on 24 September 1919. A Latvian representative, Kārlis Zariņš, was appointed to Helsinki already on 03 April 1919, but he did not actually arrive in Helsinki until 26 November 1919. The first Finnish representative to Latvia, A. Herman, arrived in Rìga also on 26 November 1919. When Finland recognised Estonia de iure on 07 June 1920 , it came as a great shock to the Latvian government as they had assumed that Latvia's and Estonia's relations with Finland were equal. Despite the efforts of Zarinš and an agreement in principle to recognise Latvia de iure by the Finnish President in October 1920 (albeit together with Poland), recognition was delayed until the Great Powers recognised Latvia de iure on 26 January 1921. Lack of de iure recognition was no obstacle to the various conferences involving Finland and the Baltic States during 1919-1921 - Rīga September 1919, Tallinn September 1919, Helsinki January 1920, and Rīga-Bulduri August 1920 - to discuss issues of mutual interest. $^{5}$

As can be seen from Table 1, despite a larger population, Finland was less urbanised than Latvia in the interwar period. Nevertheless, their economic structures were similar with Latvia having a slightly larger \% share in GDP of agriculture and forestry while Finland had a slightly larger \% share in GDP of industry. Interestingly, Latvia's average annual growth rates both pre- and post the Great Depression were slightly higher ${ }^{6}$ as was GDP per capita.

3 See Varslavans, A. (1988) for a more detailed examination of this period.

4 Nevertheless, Latvia's first President, Jānis Čakste, visited Finland in May 1926. The Finnish President, Lauri Kristian Relander, visited Latvia in June 1926.

5 See Kaslas (1976), pp. 126-142 for a detailed examination of these conferences.

6 Of course, Latvia started from a much lower base. 
Table 1. Selected economic indicators for Latvia and Finland in the interwar period

\begin{tabular}{|l|c|c|}
\hline & Latvia & Finland \\
\hline Population (millions) & $2(1939)$ & $3.7(1939)$ \\
\hline Share of urban population (\%) & $34.6(1935)$ & $26.8(1940)$ \\
\hline GDP* per capita & $4048(1938)$ & $3589(1938)$ \\
\hline $\begin{array}{l}\text { Average annual growth rate (GDP per } \\
\text { capita) 1920-1929 }\end{array}$ & 5.31 & 4.94 \\
\hline $\begin{array}{l}\text { Average annual growth rates (GDP per } \\
\text { capita) 1929-1938 }\end{array}$ & 4.1 & 3.09 \\
\hline $\begin{array}{l}\text { \% share in GDP of agriculture and } \\
\text { forestry }\end{array}$ & $39.2(1938)$ & $33.4(1938)$ \\
\hline$\%$ share in GDP of industry & $20.5(1938)$ & $23.2(1938)$ \\
\hline
\end{tabular}

* GDP measured in 1990 International Geary-Khamis dollars

Sources: Darbiṇš, A. \& Vitin̦š, V. (1947); Broadberry. S. \& O’Rourke, K. H. (2016); Hjerppe, R. (1989)

\section{Latvian-Finnish Economic Relations 1919-1940}

Some Finnish and Latvian trade was already been in existence prior to the Finnish recognition of Latvia de facto. For example, in second half of 1919 (from 01 July), Latvian exports to Finland totalled 7743 lats $^{7}$ and imports from Finland totalled 16178 lats. $^{8}$

In the interwar years, Latvian and Finnish economic relations was mainly confined to foreign trade and investment although other forms of economic relations such as tourism were also important.

Latvia's foreign trade in the interwar was based in large measure on a system of commercial and trade treaties. By 1929, Latvia had concluded commercial treaties with all important European states (except Spain) including a Commercial and Navigation Treaty between Latvia and Finland in 1924. They provided the regulatory framework within which were stated the obligations undertaken by Latvia in its foreign trade relations with its trading partners up to 1931. All these treaties contained the Most Favoured Nation (MFN) principle, as well as in practically all, the Baltic and Russian clause. The Baltic and Russian Clause stipulates that the priority rights and privileges, allowed to Estonia, Finland, Lithuania and Russia, may not be made applicable to other contracting states by virtue of the mostfavoured-nation principle.

7 Latvian roubles in 1919-1922 have been converted to Latvian lats in accordance with the rate set by the State Statistical administration -1 lat $=50$ roubles.

8 Ekonomists, 1920, No. 11, p. 327-328. 
The Commercial and Navigation Treaty between Latvia and Finland was signed on 23 August 1924 and came into force on 09 July 1925. The case of Finland, however, was different in that Finland in her commercial treaties (except the Treaty with Great Britain), had not included a "Latvian" clause, which similarly to the "Finnish" clause in Latvian treaties would allow her to give preferential treatment to Latvia. Therefore, it was possible to only conclude a trade treaty with Finland based on the MFN principle alone, although Latvia expressed at the same time the desire that Finland should include a Latvian clause (similar to the Estonian clause in Finnish treaties ${ }^{9}$ ) in her treaty system. This was never done. A Commercial Agreement between Finland and Latvia, supplementing the Commercial and Navigation Treaty between Latvia and Finland of 1924, and containing trade balancing provisions was signed 28 March 1936 and came into force on 15 April 1936.

\section{Latvian-Finnish Trade 1920-1940}

As noted previously, some Latvian-Finnish trade had occurred in 1919. The value of Latvian imports from and exports to Finland can be seen in the Figure 1.

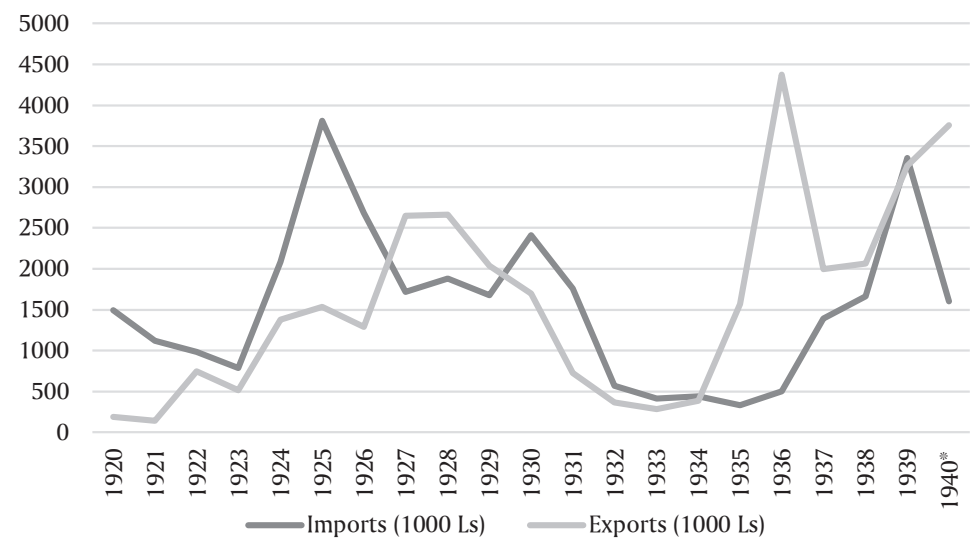

Figure 1 Latvia-Finland Imports and Exports 1920-1940

* First 8 months of 1940

Sources: Latvijas Statistika Gada Grāmata 1920-23 [Latvian Statistical Year Book 1920-23] Rīga: Valsts Statistiskā Pārvalde; Latvijas ārējā tirdzniecība un transits - 1924-1939. [Latvian Foreign Trade and Transit. 1924-1939.] Rīga: Valsts Statistiskā Pārvalde; January-December 1939 LVVA 6824f, 1 apr., 80l, p. 7; January-August 1940 - LVVA 1308f, apr. 9, 1906l, p. 57

9 Article 20 of the 1924 Treaty contained an Estonian clause for Finland and an Estonian and Lithuanian clause for Latvia. 
As Figure 1 shows, from a low start imports increased substantially after the signing of the trade agreement and in 1925 reach their highest value - just under four million lats. Exports, on the other hand, increased more slowly with a peak in 1928 with a value of over two and a half million lats. Both imports and exports fell with Great Depression, but slowly started to rise from 1934 with imports reaching their peak in 1939 and exports in 1936. Generally, exports exceeded imports in the late 1920 s and again in the late 1930s.

\section{Latvian Exports to Finland}

Latvia's main exports to Finland were Bone meal, Gypsum and gypsum products, Rubber products (including rubber galoshes), Linoleum, Radios, Paints, inks and paint compounds, and Seeds (flax and clover) (See Table 2).

Table 2. Latvia's Main Exports to Finland

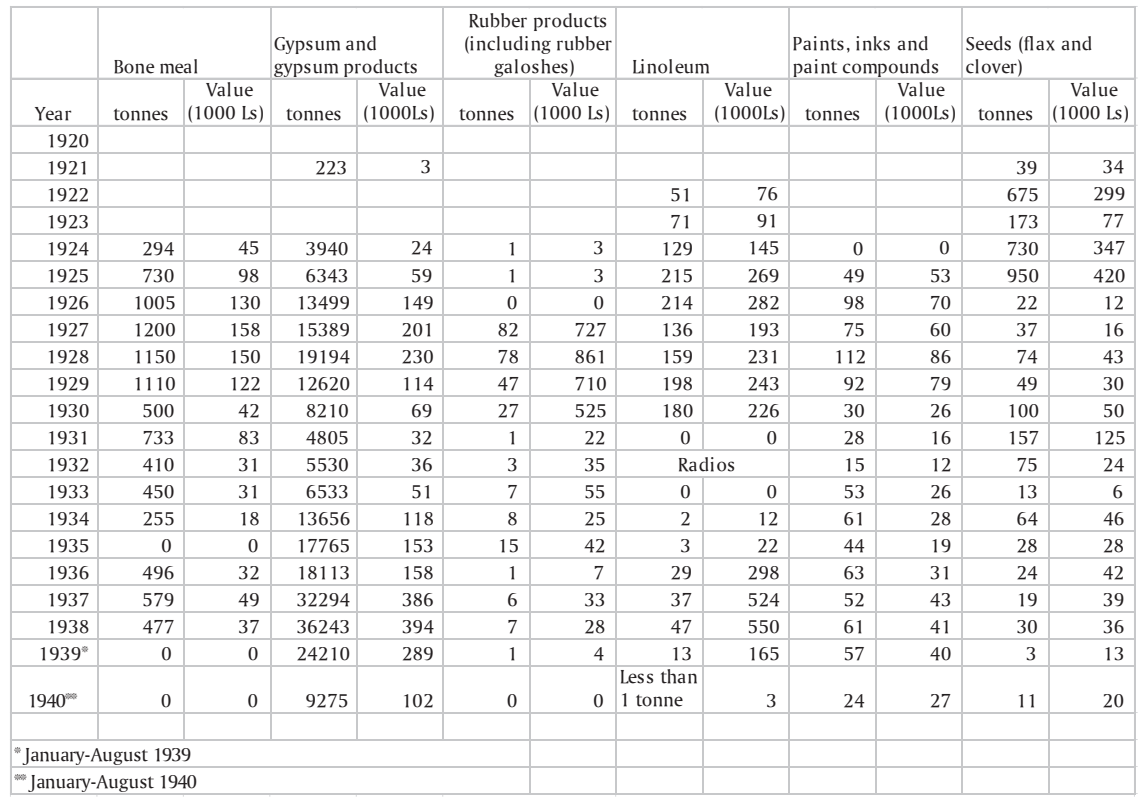

Sources: Latvijas Statistika Gada Grāmata 1920-23 [Latvian Statistical Year Book 1920-23] Rīga: Valsts Statistiskā Pārvalde; Latvijas ārējā tirdzniecība un transits - 1924-1939. [Latvian Foreign Trade and Transit. 1924-1939.] Rīga: Valsts Statistiskā Pārvalde; Mēneša Biletens Nr. 10, oktobris 1939 [Monthly Bulletin, No. 10, October 1939], p. 1057; January-August 1940 - LVVA 1308f, apr. 9, 1906l, p. 57 
Bone meal was a steady if fluctuating export product to Finland reaching its peak in 1927. The largest export in terms of volume if not value was Gypsum and gypsum products reaching a peak of 394 thousand lats in 1938. Rubber products (including rubber galoshes) were a steady, but very small part of exports as were Paints, inks and paint compounds, and Seeds (flax and clover).

Linoleum was an important export to Finland in the 1920s. Linoleum in Latvia was produced by the Liepāja branch of the Swedish entrepreneurial family firm of Wicander (Linoleum Aktiebolaget Forshaga), the "Liepāja Cork and Linoleum Factory", which before the First World War had produced linoleum for the Russian market. After the war the factory renewed production, but already in 1922 was subject to the control of an international linoleum cartel based in Britain. However, in 1927, the Wicander firm sold its Liepāja branch to another cartel, which was based in Germany. The factory completely ceased production in 1930 and linoleum disappeared from the foreign trade of Latvia and from exports to Finland. Its place was to a certain extent taken up by the export of radios in the 1930s, the value of which exceeded that of gypsum exports reaching a peak of 550 thousand lats in 1938. Latvian-made radios were popular throughout the Nordic region.

Latvia also exported various quantities of animal products (such as animal intestines), plant products (such as peas and vetch); flax and flax products, machinery, hides and furs and haberdashery, as well as small quantities of other goods.

\section{Latvian Imports from Finland}

Latvia's main imports from Finland were Cellulose, Agricultural machinery, Knives and knife products, Metals and metal products, Textiles and, surprisingly, Paper and paper products. The amounts and value of Latvia's main imports imported from Finland in the interwar period are shown in Table 3.

Cellulose was a small, but important import in the 1920s. However, it tapered off in the 1930s as Latvia established its own cellulose factories. Similarly, agricultural machinery imports from Finland were important in the 1920s, but became less so as Latvia's own industries started to produce similar goods. An interesting import was knives and knife products, which was always listed as an important import despite the small quantities. Textile imports were important in 1920s, but again tapered off as Latvia produced its own textiles in the 1930s. Metals and metal products were a small, but steady import throughout the interwar period. Curiously, a steady and important import was paper and paper products given that Latvia itself was a major exporter of such products. 
Table 3. Latvia's Main Imports from Finland

\begin{tabular}{|c|c|c|c|c|c|c|c|c|c|c|c|c|}
\hline \multirow[b]{2}{*}{ Year } & \multicolumn{2}{|c|}{ Cellulose } & \multicolumn{2}{|c|}{$\begin{array}{l}\text { Agricultural } \\
\text { machinery }\end{array}$} & \multicolumn{2}{|c|}{$\begin{array}{l}\text { Knives and knife } \\
\text { products }\end{array}$} & \multicolumn{2}{|c|}{$\begin{array}{l}\text { Paper and paper } \\
\text { products }\end{array}$} & \multicolumn{2}{|l|}{ Textiles } & \multicolumn{2}{|c|}{$\begin{array}{l}\text { Metals and metal } \\
\text { products }\end{array}$} \\
\hline & tonnes & $\begin{array}{c}\text { Value } \\
(1000 \text { Ls) }\end{array}$ & tonnes & $\begin{array}{l}\text { Value } \\
\text { (1000Ls) }\end{array}$ & tonnes & $\begin{array}{c}\text { Value } \\
\text { (1000 Ls) }\end{array}$ & tonnes & $\begin{array}{l}\text { Value } \\
\text { (1000Ls) }\end{array}$ & tonnes & $\begin{array}{l}\text { Value } \\
\text { (1000Ls) }\end{array}$ & tonnes & $\begin{array}{l}\text { Value } \\
\text { (1000 Ls) }\end{array}$ \\
\hline 1920 & & & & & & & & & & & & \\
\hline 1921 & 82 & 13 & 84 & 185 & & & 664 & 539 & 8 & 79 & 23 & 2 \\
\hline 1922 & 231 & 71 & 30 & 44 & & & 221 & 180 & 20 & 192 & 1 & 1 \\
\hline 1923 & 201 & 64 & 18 & 44 & & & 50 & 64 & 16 & 184 & 45 & 1 \\
\hline 1924 & 796 & 299 & 39 & 81 & & & 43 & 97 & 80 & 876 & 0 & 0 \\
\hline 1925 & 1252 & 486 & 58 & 157 & & & 43 & 68 & 273 & 2156 & 451 & 1 \\
\hline 1926 & 1091 & 453 & 17 & 31 & & & 148 & 105 & 160 & 1273 & 0 & 0 \\
\hline 1927 & 220 & 83 & 39 & 66 & & & 256 & 137 & 112 & 865 & 0 & 0 \\
\hline 1928 & 0 & 0 & 64 & 76 & & & 64 & 93 & 121 & 915 & 0 & 0 \\
\hline 1929 & 377 & 140 & 72 & 117 & 8 & 70 & 79 & 109 & 108 & 687 & $\begin{array}{l}\text { Less than } \\
1 \text { tonne }\end{array}$ & 1 \\
\hline 1930 & 23 & 4 & 52 & 121 & & & 322 & 209 & 196 & 1254 & & \\
\hline 1931 & 740 & 193 & 28 & 57 & 2 & 23 & 788 & 302 & 142 & 738 & & \\
\hline 1932 & 1187 & 190 & $\begin{array}{l}\text { Less than } \\
1 \text { tonne }\end{array}$ & 2 & 1 & 13 & 79 & 75 & 17 & 60 & & \\
\hline 1933 & 1222 & 160 & 2 & 8 & 1 & 11 & 6 & 5 & 11 & 40 & & \\
\hline 1934 & 1981 & 310 & 4 & 12 & $\begin{array}{l}\text { Less than } \\
1 \text { tonne }\end{array}$ & 4 & 26 & 15 & 5 & 14 & & \\
\hline 1935 & 259 & 44 & 7 & 22 & 1 & 9 & 49 & 33 & 0 & 0 & & \\
\hline 1936 & 327 & 58 & 6 & 22 & 1 & 14 & 42 & 35 & 0 & 0 & 11 & 4 \\
\hline 1937 & 836 & 180 & 11 & 55 & 1 & 20 & 69 & 79 & 14 & 94 & 225 & 201 \\
\hline 1938 & 387 & 73 & 27 & 120 & 1 & 22 & 2178 & 569 & 13 & 100 & 104 & 34 \\
\hline $1939^{*}$ & 708 & 178 & 31 & 122 & 0 & 0 & 4525 & 1052 & 0 & 0 & 0 & 0 \\
\hline $1940^{\text {tak }}$ & 718 & 288 & 7 & 46 & $\begin{array}{l}\text { Less than } \\
1 \text { tonne }\end{array}$ & 2 & 1803 & 781 & 0 & 0 & 32 & 18 \\
\hline \multicolumn{13}{|c|}{ "January-August 1939} \\
\hline \multicolumn{6}{|c|}{ January-August 1940} & & & & & & & \\
\hline
\end{tabular}

Sources: Latvijas Statistika Gada Grāmata 1920-23 [Latvian Statistical Year Book 1920-23] Rīga: Valsts Statistiskā Pārvalde; Latvijas ārējā tirdzniecība un transits - 1924-1939. [Latvian Foreign Trade and Transit. 1924-1939.] Rīga: Valsts Statistiskā Pārvalde; Mēneša Biḷetens Nr. 10, oktobris 1939 [Monthly Bulletin, No. 10, October 1939], p. 1057; January-August 1940 - LVVA 1308f, apr. 9, 1906l, p. 57

During the interwar period Latvia imported a whole range of Finnish goods in various quantities including minerals and mineral products, plywood, chemicals and chemical products, hides and furs, paving stones, and instruments, as well as small quantities of other goods.

\section{Finnish investments in Latvia 1925-1939}

Foreign capital in Latvia was mainly invested in banking, industry, transport and trade. By 1927, over $60 \%$ of the equity capital of all Latvian joint-stock banks ${ }^{10}$ was foreign owned, while foreign capital comprised $27.8 \%$ of aggregate capital in insurance, 33.9\% in trade (commerce), 63.1\%

${ }^{10}$ For a brief overview of banking in Latvia in the interwar period see Hiden (2000), pp. 133-149. 
in transport and about 50\% in industry. ${ }^{11}$ Many investors hoped that from Latvia they would be able to expand in the huge Russian market. Figure 2 provides an overview of Finnish investments in the interwar period.

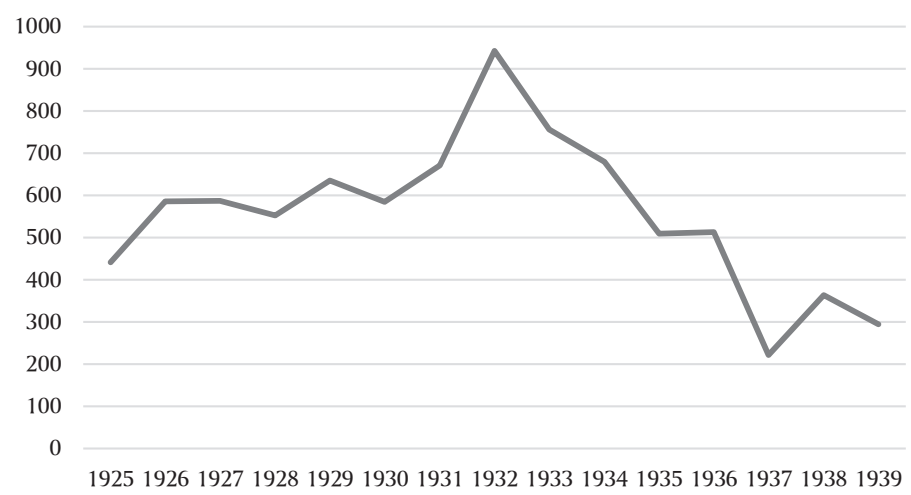

Figure 2. Finnish investments in the Company Capital of Latvian Undertakings (as at 1 January). 1925-1939 (1000 lats)

Sources: Latvijas Statistiskā gada grāmata. 1929, 1939 [Latvian Statistical Yearbooks 1929, 1939] - Rīga: Valsts Statistiskā Pārvalde; Statistikas tabulas [Statistical Tables] - Rīga: Latvijas PSR Tautsaimniecības Statistikas pārvalde, 1940

The peak year for Finish investments was 1932, when investments totalled 943000 lats. Finnish investments were mainly in the metal-working industry sector $(64.8 \%$ of total Finnish investments in 1931), followed by trade $(29.8 \%)$, and some other minor investments.

The onset of the Great Depression steadily reduced the value of Finnish investments in Latvia. From the peak in 1932 Finnish investments were reduced to 680000 lats in 1934 . The decrease accelerated after 1934, when the nationalistic Ulmanis regime began to systematically reduce the amount of the foreign investment stock. Foreign investment stock in the company capital of Latvian undertakings overall was reduced from $50.4 \%$ in 1934 to $25.4 \%$ in 1939 of which the reduction in industry was from $52.4 \%$ in 1934 to $31.9 \%$ in 1939 , in commerce from $35.9 \%$ to $28.2 \%$ and in finance and banking from $62.4 \%$ to $9.7 \%{ }^{12}$ As can be seen in Figure 2, Finnish investments had been reduced from the peak in 1932 to a mere 222000 lats by 1937 . The slight upturn in 1938 can probably be attributed to a general economic upturn trend (various other countries (for example, Poland) also increased their investments in Latvia in 1938).

\footnotetext{
${ }^{11}$ The Latvian Economist (1928), p. 24.

${ }^{12}$ Finanču un kredita statistika (1939), p. 172.
} 


\section{Latvia and the Winter War}

After the Soviet Union invaded Finland on 30 November 1939, the majority of Latvians sympathised with the Finns. Despite the fact that by this time Latvia (together with the other Baltic States) had become a "protectorate" of the Soviet Union with Red Army units stationed in military bases throughout the country, Latvia was still nominally independent. This was reflected in the newspaper coverage of the conflict, with the newspapers printing press releases from both Finland and the USSR side-by-side. ${ }^{13}$

The official position of the government was strict neutrality in the conflict. The Latvian government however continued to recognise the government in Helsinki and did not expel Finnish representatives from Latvia. On 14 December 1939, the Soviet Union was declared an aggressor and was expelled from the League of Nations. Latvia and the other Baltic States abstained from voting.

Nevertheless, as was noted previously, economic relations, especially trade continued throughout the conflict period. In the four months from 01 September to 31 December 1939, Latvia imported 1314000 lats worth of goods from and exported 330000 lats worth of goods to Finland. ${ }^{14}$ Similarly, in the four months from 01 January 1940 to 30 April 1940, Latvia imported 26000 lats worth of goods from and exported 131000 lats worth of goods to Finland. ${ }^{15}$ Essentially, the goods exported and imported were similar to previous years, with food stuffs taking up a larger proportion. ${ }^{16}$

\section{Conclusion}

In the interwar years, Latvian and Finnish economic relations was mainly confined to foreign trade and investment although other forms of economic relations such as tourism were also important. Nevertheless, despite geographical proximity and the advantage of shorter sea routes than to Britain or Germany, the fact of similar export products made significant inter-regional trade between Latvia and Finland unprofitable.

In 1929, when Latvian foreign trade reached its pre-Depression peak, Latvian exports to Finland made up $0.74 \%$ of total Latvian exports, and Finnish imports made up $0.46 \%$ of total Latvian imports. However, in 1937 , when Latvian foreign trade reached its post-Depression peak, exports to

${ }^{13}$ For a detailed examination of Latvian press coverage at this time see Žigure, A. V. (2018), pp. 213-227.

${ }^{14}$ LVVA, 6824f, 1apr, 80l, p. 7.

${ }^{15}$ LVVA, 6824f, 1apr, 80l, p. 2; 1308f, 9apr, 1899l, p. 49; 1905l, p. 49; 1904l, p. 49.

${ }^{16}$ For example, on 01 February 1940, a shipment of 5000 tonnes of rye was organised for Finland through Sweden, LVVA, 2575f, 17apr, 761, p. 21. 
Finland were only $0.8 \%$ of total Latvian exports, and imports from Finland were only $0.6 \%$ of total Latvian imports. One suspects that the figures from the point of view of Finland would be significantly less. In other words, trade and thus economic relations were of marginal significance to both countries in the interwar period.

It is interesting to note that in 2019, Latvian exports to Finland totalled 470.8 million EUR or $2.6 \%$ of total Latvian exports (mainly metals and metal products, machinery, food industry products, timber and timber products). Whilst imports from Finland totalled 754.4 million EUR or $4.0 \%$ of total Latvian imports (mainly mineral products, chemical industry products, electrical goods, and vehicles). At the end of 2019, total Finnish FDI in Latvia was 539 million EUR, whilst total Latvian FDI in Finland was 19 million EUR. There were some 340 Finnish companies registered in Latvia in 2019 (mainly involved in construction (both building and roads), and food and drink manufacturing). ${ }^{17}$

\section{REFERENCES}

Broadberry, S. \& O'Rourke, K. H. (2016). The Cambridge Economic History of Modern Europe, Vol. 2: 1870 to the Present. Cambridge: Cambridge University Press.

Darbiṇš, A. \& Vitinnš, V. (1947). Latvija: Statistisks pārskats [Latvia: A Statistical Overview]. Germany: P. Mantinieka \& E. Ķiploka Apgadi.

Ekonomists, No. 22, 30.11.1934.

Finanču un kredita statistika 1939. g [Finance and Credit Statistics] (1939). Rīga: Valsts statistiskā pārvalde.

Hiden, J. (2000). On Banks and Economic Trends in Latvia 1918-1940. In: Transformation and Integration in the Baltic Sea Area. Ed. by P. Falk and O. Krantz. Umeå: Umeå University, pp. 133-149.

Hjerppe, R. (1989). The Finnish Economy 1860-1985. Helsinki: Bank of Finland.

Kaslas, B. J. (1976). The Baltic Nations - the Quest for Regional Integration and Political Liberty. Pittston, USA: Euramerica Press.

Krasnais, V. (1980). Latviešu kolonijas [Latvian Colonies]. Melbourne: Kārḷa Zariṇa Fonds

The Latvian Economist (1928). Rīga: Ministry of Finance.

Varslavans, A. (1988). Baltic Alliance and International Politics in the First Part of the 1920s, in Hides, J. \& Loit, A. (eds), The Baltic in International Relations between the Two World Wars. Stockholm: Acta Universitatis Stockholmiensis, University of Stockholm, pp. 43-58.

LVVA, Latvijas Valsts Vēstures arhīvs [Latvian State Historical Archives].

Žìgure, A. V. (2018). Ziemeḷzemes cēlā tauta [The Noble People of a Nordic Country]. Rīga: Zinātne.

${ }^{17}$ Data from the Central Statistical Bureau of Latvia. 